\title{
THE IMPACT OF AGRICULTURE ON THE WATERS OF THE IDAHO PORTION OF THE SNAKE RIVER BASIN, USA
}

\author{
ROBERT L. MAHLER \\ Department of Soil and Water Systems, University of Idaho, USA.
}

\begin{abstract}
The Snake River Basin is the largest sub-basin of the International (Canada and USA) Columbia River Basin in North America and covers $280,000 \mathrm{~km}^{2}$. Over $70 \%$ of the Snake River Basin is within Idaho. The Snake River is $1,674 \mathrm{~km}$ in length and the majority of the Basin is dry with annual precipitation averaging less than $300 \mathrm{~mm}$. The snowpack in the mountains of the northern part of the Basin provide significant surface and groundwater resources for the Idaho portion of the Snake River Basin. Consequently, surface water and groundwater withdrawals exceed $64,000,000,0001 /$ day. Over $86 \%$ of the withdrawn water is currently used on 1,500,000 ha of irrigated agricultural land. The purpose of this paper is threefold: (1) to understand current and future pressure on the limited water resources of the Snake River Basin, (2) to gain an understanding of the value of the public places on the water resource and agriculture, and (3) to suggest sustainable practices that can be used in the future to support population growth, wise water resource use, and agriculture in the Snake River Basin. Currently, the basin does not have excess water, so water-use distribution must change as the population grows. Currently, the human population within the basin is increasing at the rate of 25,000 to 30,000 people per year. A significant portion of this growth has caused the conversion of irrigated farmland to cities. Thus, irrigated agriculture's share of water will decline from $86 \%$ today to less than $72 \%$ by 2040 . Mailbased surveys were used to understand how the public view the Snake River Basin's water resource. The majority of Snake River Basin residents are supportive of agriculture's use of water (84\%) and consider irrigated agriculture an important cultural aspect of Idaho (77\%). The following four strategies should be the focus of a long-term sustainable plan: (1) use land-use planning to determine which agricultural land should be protected from urban development, (2) improve water use and irrigation efficiency in irrigated agriculture, (3) reduce the amount of irrigated land devoted to low value crops, and (4) provide consumer education about the agriculture - water resource - population nexus in the Snake River Basin of Idaho.

Keywords: Public concerns, Water issues, Public opinion, Water quality, Water quantity.
\end{abstract}

\section{INTRODUCTION}

The Snake River Basin in the Pacific Northwest has traditionally been a large rural region that has supported a thriving agriculture industry. This relatively arid region has been blessed with a substantial annual mountain snowpack that has provided plenty of surface and groundwater for the agricultural industry. The favorable dry climate has allowed the production of over 180 irrigated crops and supported a large animal industry. In the past 30 years the region has attracted substantial numbers of new residents. This population increase along with substantial projected population growth over the next several decades will adversely impact both water resources and agriculture unless a sustainable management plan is developed and implemented.

\section{BACKGROUND}

Idaho occupies over $70 \%$ of the Snake River Basin in the Pacific Northwest (Fig. 1). Agriculture is Idaho's major industry, as it, and associated food processing accounts for over $20 \%$ of the state's gross product. Idaho's agriculture is important, of high value, and diverse. Today the state contains 25,000 farms and ranches spread across 5,600,000 ha and is considered the fourth largest agricultural state in the western USA. Annual farm receipts exceed $\$ 7,000,000,000$. Approximately, 1,500,000 ha are irrigated for agricultural use. 


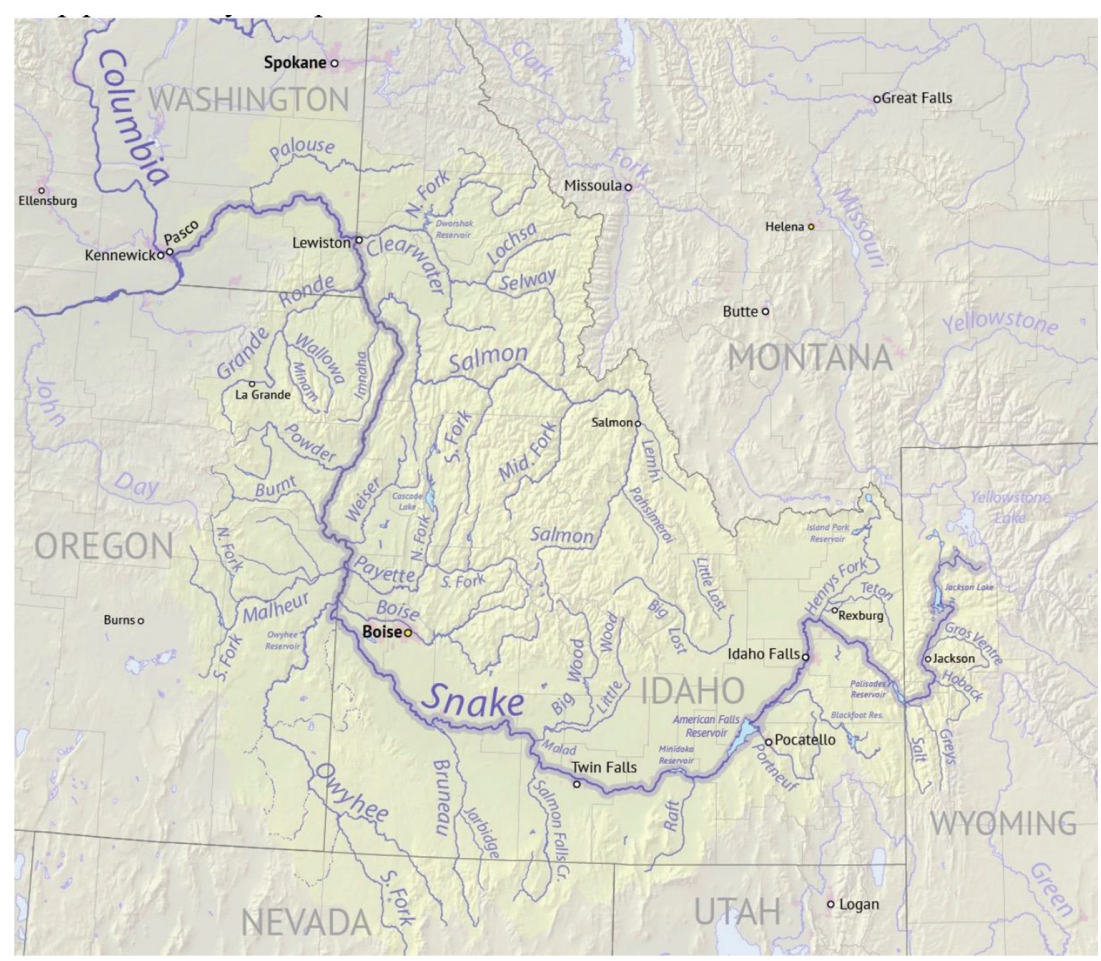

Figure 1: Map of the Snake River Basin (in color) in Pacific Northwest Region of the USA. Map provided by Wikipedia.

Although very important today, modern agriculture in Idaho is relatively new. Historical evidence indicates that modern farming in Idaho began in the early 1800s. Henry Spalding, a catholic missionary, introduced irrigation to the Nez Perce Native Americans in northern Idaho in 1838 [1]. In the 1850s irrigation was introduced to the Shoshone Native Americans in southern Idaho by Mormon missionaries. Agriculture started to rapidly develop in the 1860s when early Mormon pioneers moved into Idaho from the Great Salt Lake area of Utah. This was the beginning of large-scale irrigated agriculture in Idaho [2]. Many of the early ditches dug to move water to fields during this period are still in use. Early settlers were quick to establish farmsteads all along the Snake River Plains and construct irrigation systems that would enable early communities to be sustainable. By the 1890s irrigated agriculture had spread west into the Boise Valley. Agriculture soon passed mining as the cornerstone of Idaho's economy. Where rainfall was less limited and irrigation unavailable dryland farming also became important in the Snake River Basin.

Idaho ranks within the top 10 states in the production of livestock and 25 different crops [3,4]. Idaho's top 10 agricultural commodities ranked from highest value are: (1) milk, (2) cattle and calves, (3) potatoes (Solanum tuberosum), (4) hay, (5) wheat (Triticum species), (6) sugar beets (Beta vulgaris), (7) barley (Hordeum vulgare), (8) dry edible beans (Phaseolus species), (9) grain corn (Zea mays), and (10) onions (Allium cepa) [4]. The dairy industry ranks first in value in Idaho. Over 600,000 dairy cows produce 6,000,000,000 kg of milk and $400,000 \mathrm{~kg}$ of cheese. Beef production ranks 13th in the USA with approximately $6,000,000,000$ head. Idaho produces over one-third of the USAs potato crop and is so famous 
for its high-quality potatoes that it is known as the 'potato state.' Idaho ranks second in the production of alfalfa (Medicago sativa) in the USA. Over 80\% of Idaho's hay crop is alfalfa. A large portion of the alfalfa hay is used to feed dairy cows. Wheat is the state's second most important crop with an annual value about $\$ 500,000$. Over half of the wheat crop is exported outside the USA. Idaho ranks second in sugar beet production and produces $20 \%$ of the USAs sugar from this crop. Although not listed in the top 10 commodities, seed production is also a very important agricultural crop. Idaho-grown seed is exported to over 120 countries. A significant portion of onion, turnip (Brassica rapa), carrot (Daucus carota), lettuce (Lactuca sativa), alfalfa, and bluegrass seed (Poa pratensis) planted in the world is grown in Idaho.

Current and future population growth on the Idaho portion of the Snake River Basin poses challenges for the agriculture industry and the amount of and distribution of water resources available. The farm community, water-planning entities and policy makers are aware of the challenges and potential changes in the use of water and land resources the future will present. The purpose of this paper is three-fold: (1) to understand current and future pressures on the limited water resource of the Snake River Basin, (2) to gain an understanding of the value the public places on the water resource, and agriculture, and (3) to suggest sustainable practices that can be used in the future to support population growth, wise water resource use and agriculture in the Snake River Basin. This paper is divided into four sections - (1) population growth, (2) water and irrigation management, (3) public opinion about water issues, and (4) potential solutions to presented problems.

\section{METHODOLOGY}

Historic Idaho population information was obtained from US Census data sets from 1920, 1930, 1940, 1950, 1960, 1970, 1980, 1990, 2000, and 2010 [5]. Population estimates for Idaho in 2016, 2017, 2018, and 2019 were based on US Census estimates and the Idaho Department of Commerce. Idaho population projection information from 2020 to 2040 were based on both federal and Idaho state agency data and estimates. Specific population projection data for counties and cities in southwestern Idaho used data and expert opinions from the city planning departments of Boise, Caldwell, Meridian, and Nampa.

Water-use and irrigation management information were obtained from various Idaho state agencies including (1) Idaho Department of Water Resources (IDWR), (2) Idaho Department of Environmental Quality (IDEQ), Idaho Department of Agriculture (IDA) and (4) the University of Idaho Cooperative Extension System (UI-CES). A portion of the irrigation management data and projections were obtained from the Natural Resources Conservation Service in Idaho (USDA-NRSC-Idaho). Various water experts in several other agencies contributed data, forecasts and opinions about future water management in Idaho.

A survey instrument was developed to access public opinions about population growth and water issues in Idaho. This survey instrument contained six specific questions that were used to understand public perceptions about population growth and water use on the Idaho portion of the Snake River Basin. The surveyed public was asked their opinion of the following six statements:

S-1: Fast population growth in Idaho is a concern to me. Possible answers: Yes, No, No opinion.

S-2: Over the next 40 years population growth will have a negative impact on the amount of Idaho's water resources available for human use. Possible answers: Yes, No, No opinion. 
S-3: The quantity of Idaho's groundwater resources is diminishing. Possible answers: Yes, No, No opinion.

S-4: The quality of Idaho's groundwater resources (aquifers) is diminishing. Possible answers: Yes, No, No opinion.

S-5: I support the use of water by agriculture in Idaho. Possible answers: Yes, No, No opinion.

S-6: I consider agriculture an important cultural aspect of Idaho. Possible answers: Yes, No, No opinion.

In 1988, 1998, 2008, and 2018 these six survey statements were embedded into 30-question surveys that were sent to over 900 residents of Idaho. The surveys target audience was a representative sample of the 1,3000,000+ adult residents of Idaho. Each identical survey was developed and delivered to the public via the US Postal Service using the Dillman methodology [6,7]. A sufficient number of completed surveys was the goal to result in a sampling error of less than 6\% [7]. The survey process was also designed to receive a completed survey return rate in excess of 50\%. Addresses were obtained from a professional social sciences survey company (SSI, Norwich, CT). Four mailings were planned to achieve the $50 \%$ return rate $[6,7]$. The mailing strategy used was identical in all four surveys that had been conducted in the region since $1998[8,9]$. It only took three mailings to achieve the target return rate of $50 \%$ in 1988, 1998, 2008, and 2018.

Survey answers were coded and entered into Microsoft Excel. Missing data were excluded from the analysis. The data were analyzed at two levels using SAS [10]. The first level of analysis generated frequencies, while the second level evaluated opinion changes over time $[6,7,10]$. Since similar response rates were observed in all survey years, data analysis procedures were identical for each sampling.

\section{RESULTS AND DISCUSSION}

The discussion section of this paper is developed to first lay out population growth and water resources issues facing the Snake River Basin. Past and current public views about population growth, water resources and the importance of agriculture are then be evaluated. Finally, actions that allow population growth, effective water resource use and agriculture to sustainably coexist in the Snake River Basin are proposed.

\subsection{Population growth}

On a percentage basis Idaho has been one of the five states with the fastest rate of population growth since 2000. This trend is expected to continue over the next three decades. As of 2018 there were 1,753,000 residents of the state [5]. Currently, the annual population growth rate exceeds $0.9 \%$, and over the next 25 years the growth rate should be three times the growth rate of the rest of the USA. Geographically, most of the state as well as the population is located within the Snake River Basin (Table 1; Fig. 2). The percentage of the state's population living in the Snake River Basin has increased from 65\% in 1900 to over 82\% in 2018.

Population growth within the state is uneven with the fastest growth being in the southwestern portion of Idaho within the Boise area of the Snake River Basin (Fig. 2). Idaho's population was less than 1,000,000 people in 1980. Population projections for 2020, 2025, 2030, and 2040 are 1,830,000, 1,920,000, 2,010,000, and 2,240,000, respectively [5]. Despite the projected population growth Idaho will still rank in the lowest third of the 50 states from a population standpoint. 
Table 1: Historical Idaho population data for people residing inside and outside the Snake River Basin.

\begin{tabular}{lcc}
\hline Year & $\begin{array}{c}\text { Population within } \\
\text { Snake River Basin }\end{array}$ & $\begin{array}{c}\text { Population outside } \\
\text { Snake River Basin }\end{array}$ \\
\hline 1900 & 111,500 & 50,500 \\
1920 & 316,000 & 117,000 \\
1940 & 396,000 & 126,000 \\
1960 & 521,000 & 150,000 \\
1980 & 740,000 & 204,000 \\
1990 & 801,000 & 212,000 \\
2000 & $1,038,000$ & 261,000 \\
2010 & $1,281,000$ & 290,000 \\
2018 & $1,440,000$ & 313,000 \\
\hline
\end{tabular}

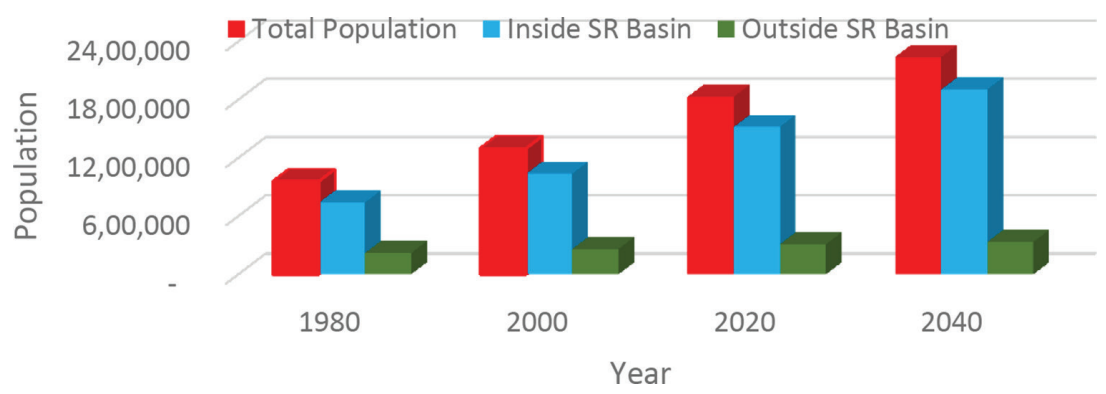

Figure 2: Historical and projected population data for the following Idaho sectors: (1) total Idaho population, (2) population within the Idaho portion of the Snake River Basin, and (3) population residing outside the Snake River Basin.

Over two-thirds of Idaho's projected population growth between 2019 and 2040 will likely occur in just three of 44 counties - Ada, Canyon, and Kootenai. Both Ada and Canyon counties are in the Snake River Basin in southwestern Idaho. Kootenai county is located outside the Snake River Basin but is within the larger Columbia Basin Watershed. Both the state capital, Boise, and fastest growing city, Meridian, are in the fast-growing Ada county. Together, Ada and Canyon counties comprise the Boise metropolitan area. In this metropolitan area annual growth exceeds $3.0 \%$. These two counties are projected to grow by over 200,000 by 2030 . Meridian, the fastest growing small city should exceed 150,000 by 2040 . Collectively, Canyon and Ada counties contain $27.1 \%$ of Idaho's population; however, this percentage may exceed 36\% by 2040.

Over the next 20 years fast population growth will spur many types of economic activity in the Idaho portion of the Snake River Basin; however, this potential growth will present challenges to agriculture and water resources. From an agricultural standpoint, Canyon county ranks second in farm income in the state. Much of the projected population increase in this 
county will come at the expense of agricultural land. In fact, some estimates indicate that up to $40 \%$ of the existing agricultural land in Canyon county may be converted to urban and suburban use by 2040 .

Population growth will also impact water resource use. Currently, $86 \%$ of water used by humans in Idaho supports irrigated agriculture. Increasing populations in the southwestern portion of the state will result in reduced agricultural water use and an increased water demand by the urban and industrial sector.

\subsection{Water use by agriculture}

Considering its relatively small population, Idaho is a large consumer of water. In fact, only four states use more water than Idaho. On a per capita water-use basis, Idahoans use more water than residents of the other 49 states. Estimated daily water-use averages 64,000,000,000 1 [11]. Actual water use is dependent on season of the year and ranges from a low of $2,000,000,0001 /$ day in January to over 200,000,000,000 1/day in the hottest part of July. Recent estimates show that approximately $86 \%$ of water withdrawn from surface and groundwater sources supports irrigated agriculture. The other $15 \%$ of water withdrawals are used for aquaculture (11\%), public supply (1.6\%), self-supplied domestic water $(0.40 \%)$, industry $(0.32 \%)$, livestock $(0.29 \%)$, mining $(0.13 \%)$, and irrigation of golf courses $(0.11 \%)[11,12]$. When irrigated agriculture, aquaculture, and livestock uses are added together, the agricultural industry accounts for $97.3 \%$ of water use in Idaho. In 2015, $70 \%$ of water withdrawals came from surface water sources, while groundwater supplied the other $30 \%$ of water needs $[12,13]$.

In years with average or above average snowfall the water resource needs for all users are adequate. Water quantity is primarily an issue in years with below average snowpack. When water shortfalls exist, irrigation districts cut back on water allotments to farmers. In the driest years local communities and individual residents may lose groundwater as their primary water source when wells run dry. Residents that rely on surface water as their primary water source can face shortfalls in the driest years. The incidence of shortfalls have increased where population growth has reduced per capita water availability.

Idaho has both water quality and water quantity issues $[14,15,16]$. Water quality is a concern for both surface and groundwater. For surface waters, primary contaminants include sediments (runoff from agriculture, range and forest lands), inorganic (phosphorus) and organic chemicals, and high temperature which hurts fisheries. For groundwater, primary contaminants include nitrates (from agriculture) and organic chemicals. Rules and regulations have been put in place to protect both surface and groundwater quality in the state. Compared to most other states, water quality in Idaho is superior.

Water quantity is a more serious issue in Idaho than water quality. As the states' population grows the demand for the limited water resources with continue to grow. It is obvious that the agriculture industry which consumes $86 \%$ of the state's water will be scrutinized as a potential water source for other industries and related activities. Consequently, the agricultural industry must prepare to use less water either by irrigating fewer ha or by increasing the efficiency of current irrigation practices. Both possibilities may be reasonable and if correctly implemented will not significantly harm the agricultural industry.

\subsection{Public opinion}

The survey methodology used in this study was not designed to be unique, but rather to be used as a tool to obtain useful information about public opinions about Idaho water issues in 
1988, 1988, 2008, and 2018. The four identical surveys achieved a completed return rate of over 55\%. 52 percent of survey respondents were female. The demographics of the survey respondents mirrored the 1990, 2000 and 2010 USA census data. Thus, the survey respondents were representative of the actual population living in Idaho. Most adults living in the Snake River Basin in Idaho have definite views on population growth, water resources and agriculture. Surveys have been conducted on these issues on a regular basis for at least the last 30 years [9].

Most Snake River Basin residents have views about population growth (Table 2). Fast population growth was a concern of only $35 \%$ of the adult residents of Idaho in 1988. This concern has grown over time, and by $2018,84 \%$ of the surveyed respondents were concerned about fast population growth. This concern about rapid population growth has statistically increased every 10 years since the initial survey was conducted.

It was not until 2008 that a majority of adults living in the Idaho portion of the Snake River Basin considered population growth as having a negative impact on water resources (Table 3 ). By 2018 four out of every five residents felt that population growth negatively impacted the

Table 2: Response to the statement: 'Fast population growth in Idaho is a concern to me,' based on surveys conducted in 1988, 1998, 2008 and 2018.

\begin{tabular}{lccc}
\hline Survey year & \multicolumn{3}{c}{ "Fast population growth is a concern to me" } \\
& Yes & No & No opinion \\
& $-\cdots$ & 40 & 25 \\
1988 & 35 & 40 & 18 \\
2098 & 42 & 21 & 18 \\
2018 & 61 & 9 & 7 \\
\hline
\end{tabular}

Statistics: 1988 vs. $2008: \mathrm{p}=0.04 ; 1988$ vs. $2008: \mathrm{p}=0.0002 ; 1998$ vs. $2018: \mathrm{p}=0.0001 ; 2008$ vs. 2018: $\mathrm{p}=0.0001$.

Table 3: Response to the statement: 'Over the next 40 years, population growth will have a negative impact on Idaho's water resources,' based on surveys conducted in 1988, 1998, 2008 and 2018.

\begin{tabular}{|c|c|c|c|}
\hline \multirow[t]{3}{*}{ Survey year } & \multicolumn{3}{|c|}{ "Population growth negatively impacts water resources" } \\
\hline & Yes & No & No opinion \\
\hline & \multicolumn{3}{|c|}{ 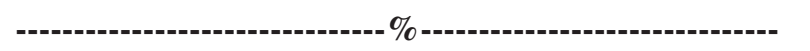 } \\
\hline 1988 & 26 & 44 & 30 \\
\hline 1998 & 34 & 42 & 24 \\
\hline 2008 & 58 & 26 & 16 \\
\hline 2018 & 80 & 16 & 4 \\
\hline
\end{tabular}

Statistics: 1988 vs. 2008: $\mathrm{p}=0.02 ; 1988$ vs. 2008 : $\mathrm{p}=0.0001 ; 1998$ vs. 2018 : $\mathrm{p}=0.0001 ; 2008$ vs. 2018 : $\mathrm{p}=0.0001$. 
states' water resources. It is important to note from the survey data that the public currently (2018) links fast population growth with undesirable impacts on water resources within the Snake River Basin.

Currently, the majority of Idaho's adult residents do not feel that the quantity of Idaho's groundwater resources are diminishing (Table 4). However, the percentage of the public believing that the quantity of groundwater resources has diminished increased from $12 \%$ in 1988 to $47 \%$ by 2018 . The percentage of the public that does not think that groundwater resources in Idaho has diminished has held steady between 1988 and 2018. Although population growth was never mentioned in this specific survey question, it is likely that it influenced public responses in 2018.

Public views on the quality of groundwater (aquifers) in Idaho are shown in Table 5. The peak in public concern about groundwater quality occurred at $40 \%$ in 1998. It is likely that a factor other than population growth accounted for these public views in the last 30 years. The highest concern level in 1998 was probably related to environmental studies in the 1990s that identified high levels of nitrates in aquifers caused by human activities. This received a lot of

Table 4: Response to the statement: 'The quantity of Idaho's groundwater is diminishing,' based on surveys conducted in 1988, 1998, 2008 and 2018.

\begin{tabular}{lccc}
\hline Survey year & \multicolumn{3}{c}{ "The quantity of groundwater is diminishing" } \\
& Yes & No & No opinion \\
\hline 1988 & --12 & 30 & 58 \\
1998 & 24 & 28 & 48 \\
2008 & 34 & 30 & 46 \\
2018 & 47 & 26 & 27 \\
\hline
\end{tabular}

Statistics: 1988 vs. 2008 : $\mathrm{p}=0.0411988$ vs. 2008 : $\mathrm{p}=0.0003 ; 1998$ vs. $2018: \mathrm{p}=0.0001 ; 2008$ vs. 2018: $\mathrm{p}=0.0006$.

Table 5: Response to the statement: 'The quality of Idaho's groundwater is diminishing,' based on surveys conducted in 1988, 1998, 2008 and 2018.

\begin{tabular}{lccc}
\hline Survey year & \multicolumn{3}{c}{ "The quality of groundwater is diminishing" } \\
& Yes & No & No opinion \\
& - & 50 & 26 \\
1988 & 24 & 38 & 22 \\
1998 & 40 & 35 & 27 \\
2008 & 38 & 35 & 28 \\
2018 & 37 & & 27 \\
\hline
\end{tabular}

Statistics: 1988 vs. $2008: \mathrm{p}=0.04 ; 1988$ vs. $2008: \mathrm{p}=0.0002 ; 1998$ vs. $2018: \mathrm{p}=0.0001 ; 2008$ vs. 2018: $\mathrm{p}=0.0001$. 
media attention, and as a result regulatory agencies in Idaho promoted the use of best management practices to minimize the introduction of chemicals into groundwaters of the state.

A large percentage of Idaho Snake River Basin residents have consistently supported the use of water by agriculture (Table 6). The percentage of support for water use by agriculture has not fallen below $84 \%$ since the survey began. Statistical differences between years were not observed. This is interesting because even though the population of Idaho has become more urban since 1988 there has been consistent overwhelming support for water use by the agricultural industry.

Residents of the Idaho portion of the Snake River Basin consider irrigated agriculture an important cultural aspect of Idaho (Table 7). Since 1988 over three-quarters of residents have considered irrigated agriculture as important culturally. However, the value of support has fallen from $91 \%$ in 1988 to $77 \%$ in 2018 . The 2018 value is still large but has probably fallen relative to obtained vales in 1988 and 1998 due to the large population influx of people moving to Idaho from other western states.

Table 6: Response to the statement: 'I support the use of water by agriculture in Idaho,' based on surveys conducted in 1988, 1998, 2008 and 2018.

\begin{tabular}{|c|c|c|c|}
\hline \multirow[t]{3}{*}{ Survey year } & \multicolumn{3}{|c|}{ "I support the use of water by agriculture in Idaho" } \\
\hline & Yes & No & No opinion \\
\hline & \multicolumn{3}{|c|}{ 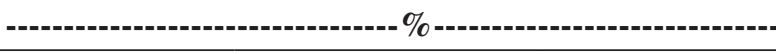 } \\
\hline 1988 & 90 & 6 & 4 \\
\hline 1998 & 85 & 10 & 5 \\
\hline 2008 & 86 & 12 & 2 \\
\hline 2018 & 84 & 10 & 6 \\
\hline
\end{tabular}

Statistics: 1988 vs. $2008: \mathrm{p}=0.05 ; 1998$ vs. 2008 : $\mathrm{p}=0.04 ; 1998$ vs. $2018: \mathrm{p}=0.02 ; 2008$ vs. 2018: $\mathrm{p}=\mathrm{NS}$.

Table 7: Response to the statement: 'I consider agriculture an important cultural aspect of Idaho,' based on surveys conducted in 1988, 1998, 2008 and 2018.

\begin{tabular}{lccc}
\hline $\begin{array}{l}\text { Survey year } \\
\text { Yes }\end{array}$ & $\begin{array}{c}\text { "Irrigated agriculture is an important cultural aspect of Idaho" } \\
\text { No opinion }\end{array}$ \\
\hline 1988 & ---10 & 4 & 5 \\
1998 & 91 & 10 & 4 \\
2008 & 86 & 10 & 10 \\
2018 & 80 & 13 & 10 \\
\hline
\end{tabular}

Statistics: 1988 vs. $2008: \mathrm{p}=0.005 ; 1998$ vs. 2008 : $\mathrm{p}=0.04 ; 1998$ vs. $2018: \mathrm{p}=0.007 ; 2008$ vs. 2018: $\mathrm{p}=\mathrm{NS}$. 
4.4 Making population growth, water use, and agriculture sustainable

It is given that population growth over the next several decades will result in the reduction of land devoted to irrigated agriculture. In addition, the amount of water that will be available to the irrigated land left intact will also be reduced. Consequently, a long-term plan to deal with these changes must be developed. The following four strategies should be the focus of a longterm sustainable management plan: (1) implementing land-use planning, (2) improving water use efficiency in irrigated agriculture, (3) reducing the amount of irrigated land devoted to low value crops, and (4) targeting education about the agriculture-water resource- population growth nexus in the Snake River Basin to residents.

Land-Use Planning. Rapid population growth will result in significant conversion of irrigated agricultural land into suburban and urban housing. It is important to protect the best agricultural land during this transition. A comprehensive plan to protect the best farm land should utilize the data resources that have been developed by the USDA-Natural Resources Conservation Service. Conversely, the poorest irrigated farmland should be targeted for landuse conversion. Land-use planning will result in the lowest amount of productivity loss for agriculture. Buffers containing prime farmland will also be desirable for the residents of the newly developed suburban areas.

Improved Water-Use Efficiency by Agriculture. The irrigated agriculture industry must get by using less water. This can be done in at least three different ways. The most obvious and easiest way is to encourage the planting of crops that require less water. With 180 different crops grown in the Snake River Basin there is room to choose crops that require less water.

The second way to reduce the use of irrigation water is to move from less efficient to more efficient irrigation systems. Currently, the three major irrigation systems - flood, sprinkler, and drip account for $40 \%, 59 \%$, and $1 \%$ of the irrigated farmland, respectively. Fields watered by flood irrigation, the least efficient irrigation system, should be converted to sprinkler irrigation. This conversion would greatly reduce the amount of water used. A portion of the sprinkler irrigated fields could be converted to drip systems which would also greatly increase water-use efficiency. Under the leadership of USDA-NRCS a significant portion of the onion ha have already been converted to drip irrigation. This has greatly increased water-use efficiency. However, the high initial cost of installing drip systems makes them only economically viable for the most valuable crops. The third option for increasing water-use efficiency would be simply increasing the price of water. This could be done for surface water sources and would provide an economic incentive for reduced water use.

Reduce Planting of Low Value Irrigated Crops. The planting of low value crops on less than prime irrigated farmland should be reduced.

Consumer Education. It is important that residents know the linkage between population growth, water resource use, and the production of food by irrigated agriculture. A good consumer education program will allow consumers to understand this relationship. In turn consumers are more likely to support the choices being made to make this a sustainable system and long-term plan.

\section{CONCLUSIONS AND RECOMMENDATIONS}

Significant change is coming to the Snake River Basin in Idaho in the next 20+ years. Significant population growth will result in the loss of irrigated farmland and will strain the availability of water resources. Consequently, a long-term plan to deal with these changes must be developed. The following four strategies should be the focus of a long-term 
sustainable management plan: (1) implementing land-use planning, (2) improving water-use efficiency in irrigated agriculture, (3) reducing the amount of irrigated land devoted to low value crops, and (4) targeting education about the agriculture-water resource-population growth nexus in the Snake River Basin to residents. In addition to these recommendations key findings of this paper include:

- Idaho's population is expected to increase by $28 \%$ in the next 21 years. This growth will come at the expense of agricultural land and the amount of water available for agriculture.

- A portion of the land base currently used for agriculture in Ada, Bonneville, Bingham and Twin Falls counties will shift to suburban and urban land uses by 2040. However, the largest shift will occur in Canyon country which currently has the second highest agricultural receipts of all Idaho counties. Between 20 and $40 \%$ of the agricultural land base in Canyon county may be converted away from agricultural land uses by 2040 .

- Most Idaho residents are concerned about rapid population growth. By 2018 four out of every five Idaho residents felt that population growth was negatively impacting the states' water resources.

- Currently, the majority of Idaho's adult residents do not feel that the quality of Idaho's groundwater resources are diminishing. However, the percentage of the public considering that the quantity of groundwater resources has diminished increased from $12 \%$ in 1988 to $47 \%$ by 2018 .

- A large percentage of Idaho Snake River Basin residents have consistently supported the use of water by agriculture. The percentage of support for water use by agriculture has not fallen below $84 \%$ since the survey study began.

- Residents of the Idaho portion of the Snake River Basin consider irrigated agriculture an important cultural aspect of Idaho. Since 1988 over three-quarters of residents have considered irrigated agriculture as important culturally.

- In 2018 irrigated agriculture consumed $84 \%$ of the states' water resources. This percentage is expected to drop to between $72 \%$ to $79 \%$ by 2040 .

- Sustainable irrigation practices should be enable agriculture to stay competitive and produce high yield commodities well into 2040 despite the reduction in water resources allocated to this activity for three reasons: (1) these will be less land that need to be irrigated because of significant land conversion from agriculture to urban and suburban uses; (2) improved irrigation efficiency will occur as more land is converted from flood to sprinkler irrigation and a conversion to drip irrigation for high value crops; and (3) less water intensive crops will become more important in cropping sequences.

\section{REFERENCES}

[1] Idaho Potato Museum, Early history of potatoes in Idaho, 2018. https://idahopotatomuseum.com/history/early-history/ (accessed September 2018).

[2] Idaho Department of Agriculture, Agriculture and irrigation in Idaho, 2018. https://digitalatlas.cose.isu.edu/geog/agirrig/agirtext/agigmain.htm (accessed July 2018).

[3] USDA/NASS, State Agriculture Overview for Idaho, 2018. https://nass.usda.gov/ Quick_Stats/Ag_Overview/stateOverview.php?state=IDAHO (accessed June 2018).

[4] Idaho State Department of Agriculture, 2018 Idaho Agriculture Facts, Idaho Department of Agriculture, 2018.

[5] US Census Bureau, Population facts for Idaho, 2018. https://census.gov.quickfacts/id (accessed July 2018). 
[6] Salent, P. \& Dillman, D., How to Conduct Your Own Survey, John Wiley and Sons, Inc.: New York, 1994.

[7] Dillman, D., Mail and Internet Surveys: The Tailored Design Method, John Wiley and Sons, Inc.: New York, 2000.

[8] Mahler, R.L., Preferred water resource information sources and learning opportunities in the Pacific Northwest. Natural Sciences Education, 47(1), p. 180014, 2018. https:// doi.org/10.4195/nse2018.07.0014

[9] Mahler, R.L. \& Barber, M.E., Using adult education to improve sustainability of water resources in the Pacific Northwest, USA. International Journal of Sustainable Development and Planning, 10(6), pp. 828-842, 2015.

[10] SAS Institute Inc., SAS Online Document 9.1.3. Cary, North Carolina: SAS Institute Inc., 2004.

[11] Maupin, M.A., Kenny, J.F., Hutson, S.S., Lovelace, J.K. \& Barber, N.L., Estimated Water Use in the United States in 2010. US Geological Survey. Circular, 1405, 2014.

[12] Murray, E.M., Idaho Water Use, 2015. US Geological Survey, 2018. https://doi. org/10.3133/fs20183036

[13] Van Steeter, M.M., Mahler, R.L. \& Mink, L.L., Quality water for Idaho: groundwater in Idaho. Idaho Agricultural Experiment Station Current Information Series, 900, 1991.

[14] Mahler, R.L. \& Keith, K.E., Idaho's Nitrate Areas of Concern. University of Idaho, College of Agriculture Current Information Series No. 1099. 2002.

[15] Harrington, H. \& Berdixsen, S., Groundwater Management Areas in Idaho: Overview as of 1998. Idaho Department of Water Resources. Boise, ID. 62, 1999.

[16] Clark, W.H., Idaho Water Quality Status Report. Idaho Division of Environmental Quality, p. 209, 1998. 